\title{
Dermatological moulage collections in the Nordic countries
}

\author{
Worm, A.-M.
}

2018-04

Worm , A-M , Sinisalo , H , Eilertsen , G , Ahren , E \& Meyer , I 2018 , ' Dermatological

moulage collections in the Nordic countries ' , Journal of the European Academy of

Dermatology and Venereology , vol. 32 , no. 4 , pp. 570-580 . https://doi.org/10.1111/jdv.14659

http://hdl.handle.net/10138/323555

https://doi.org/10.1111/jdv.14659

unspecified

acceptedVersion

Downloaded from Helda, University of Helsinki institutional repository.

This is an electronic reprint of the original article.

This reprint may differ from the original in pagination and typographic detail.

Please cite the original version. 
This is the peer reviewed version of the following article: A.-M. Worm, Dermatological moulage collections in the Nordic countries, 2018, Journal of the European Academy of Dermatology and Venereology, 4, 570580, which has been published in final form at https://doi.org/10.1111/jdv.14659. This article may be used for non-commercial purposes in accordance with Wiley Terms and Conditions for Use of Self-Archived Versions. 


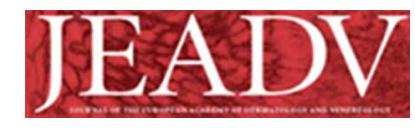

\section{Dermatological moulage collections in the Nordic countries}

\begin{tabular}{|r|l|}
\hline Journal: & Journal of the European Academy of Dermatology and Venereology \\
\hline Manuscript ID & JEADV-2017-0877.R2 \\
\hline Manuscript Type: & Original Article \\
\hline Keywords: & Moulages, Wax figures, Dermatological wax figures \\
\hline \multicolumn{2}{|l}{} \\
\hline
\end{tabular}




\section{Dermatological moulage collections in the Nordic countries}

(Running head: Moulage collections in the Nordic countries)

By

AM. Worm (1), H. Sinisalo (2), G. Eilertsen (3), E. Åhrén (4), I. Meyer (1).

1. Medical Museion, University of Copenhagen, Denmark

2. Helsinki University Museum, University of Helsinki, Finland

3. Leprosy Museum, Bergen City Museum, Norway

4. Unit for Medical History and Heritage, Karolinska Institutet, Stockholm, Sweden

Corresponding author:

Anne-Marie Worm.

Medical Museion, University of Copenhagen, Fredericiagade 18, DK-1310 Copenhagen, Denmark

Phone: (+45) 40523730

amw@dadlnet.dk 


\begin{abstract}
Background

The art of producing and acquiring dermatological wax models, moulages, flourished all over Europe in the beginning of the twentieth century, whereas very little is known about the existence of moulage collections in the Nordic countries.
\end{abstract}

\title{
Objective
}

The aim of this paper is to elucidate the presence, the origin, the production place, the use and the condition of dermatological moulage collections in the Nordic countries.

\begin{abstract}
Methods
In each Nordic country, an extensive survey was undertaken during spring 2016. Dermatological departments, museums with medical collections, persons assumed to have specific information about wax moulages as well as secondary sources were contacted and interviewed.

\section{Results}

Several hitherto undescribed collections have survived in each country, most however damaged and in disrepair. One Danish and part of a Finnish collection have been restored. Only few moulages are exhibited some have been photographed and digitalized. Denmark and Sweden have had a local moulage production. Responses to the survey indicate that the result covers all collections of dermatological moulages in the Nordic countries, though some moulages may remain in private collections unknown to the authors, or uncatalogued in museums.

Conclusion

Moulages are medical gems from bygone days before modern technology facilitated new means of communication. Restoration and appropriate storing should be considered for at least selected items from the Nordic collections.
\end{abstract}

\section{Conflict of Interest \\ None declared}

Funding source

None declared

\section{Introduction}

At the First International Congress of Dermatology and Syphilology in 1889 at Hôpital Saint-Louis, the Parisian dermatologists presented a new Museum holding thousands of wax moulages depicting skin manifestations due to dermato-venereological diseases. ${ }^{1}$ At this time, clinical photography was scarcely in use. However, with the art of moulages it was possible to present diseases in the skin in an extremely detailed threedimensional way eminent for teaching. Before that, independent centers in London, Jena and Vienna had had their own production of dermatologic moulages for decades; the meeting in Paris however fostered a breakthrough for moulage production in many other European countries. ${ }^{2}$

There is sparse information about dermatologic moulage collections and production in the Nordic countries. In a German website "Archiv für medizinische Wachsbilder (Moulagen)", Finland is the only Nordic country mentioned to have their own collection. ${ }^{3}$ The latter collection, depicting faces of children with skin 
markers of infectious diseases, was the topic of a thesis (in Finnish) from 2012. ${ }^{4}$ In Denmark a collection of moulages, mainly depicting skin changes due to lupus vulgaris, was described (in Danish) in 1982. ${ }^{5}$ It is the aim of this paper to update available information about moulage collections and the stories behind from the Nordic countries.

\section{Methods.}

During spring 2016, an extensive survey was initiated in each Nordic country. Museums with medical collections, dermatological departments, present and retired employees, together with persons with a known interest in medical history were contacted by mail and by phone. Furthermore, an inquiry was posted to certain museum Facebook pages. The initial survey asked about the existence of all types of moulages and wax models. For the purposes of this article however only dermatological wax moulages were included. When having a positive response questions posed included the number and types of moulages, whether or not they were catalogued, photographed, digitized, on display or in storage, and whether treated by conservators. The history and provenance of the moulages, including details about where and when they were manufactured were also collected. The national coordinator of this survey described the collections if accessible otherwise by their caretakers, and photographs were then sent to the national coordinator, who followed up in correspondence with the collection managers. Responses to the survey and the following communication with collection managers indicate that the result covers all collections of dermatological moulages. However, some moulages may remain in private collections unknown to the authors, or uncatalogued in museums.

Denmark.

\section{DK-1. The Finsen moulages.}

A collection of 67 wax moulages, was found at the Finsen Light Institute in Copenhagen in 1978. When and by whom these moulages had been stored in a warm basement room, inappropriate for the fragile wax material, is unknown. The moulages were dusty, dirty, and partly deformed due to pressure and heat but most were relatively well preserved. After presentation at a scientific meeting for Danish dermatologists and exhibited for a few months, the moulages were again stored in an inappropriate room. According to rather detailed information collected in 1978, the production period was between 1900 and $1930 .^{5}$ The moulages were described as technically rather alike, but without signature on the board on which they were mounted. A well-known Danish artist, Theodor Edelmann (1856-1937) seems to have made some or may be all the Finsen moulages, according to information from former employees. Edelmann was educated at the Royal Danish Academy of Art, had studied miniature wax portraiture in Vienna, and was associated with the first Scandinavian Panoptikon from its creation in 1888, for a period (1910-14) as the director. ${ }^{5-6}$ The Danish physician Niels R Finsen (1860-1904) founded modern phototherapy as the director of the Medical Light Institute in Copenhagen, the Finsen Institute and hence the name "The Finsen moulages". Niels Finsen received the Nobel Prize for Physiology and Medicine in 1903 in recognition of his work and, in particular, of the very beneficial effect on the disfiguring disease lupus vulgaris. ${ }^{7}$ The moulage production at the Finsen Institute was initiated before Niels Finsen died in 1904, as his handwritten ordination 'mouleur' was found in some patient records still stored at the Institute in 1978. ${ }^{5}$ Exact information about when and by whom the moulage production was initiated is however missing. During the First International Congress of Dermatology and Syphilology in 1889 at Hôpital Saint-Louis, Niels Finsen was still a medical student. However, less than a decade later his close coworkers presented the first convincing results of the effect of light on lupus vulgaris in Copenhagen (1897), Stockholm (1898), Paris (1898), Paris (1900) and Breslau (1901). ${ }^{8}$ In Paris dermatologists from all over the world had had their first detailed impression of the art of moulaging, and the possibilities for using moulages as teaching objects for students, nurses, doctors, and for public health education when informing about the consequences of transmissible diseases. It seems 
justifiable to conclude that the meetings in Paris inspired Niels Finsen and his co-workers to start their own moulage production, probably from 1901 when the Light Institute in Copenhagen moved to more spacious nearby buildings. ${ }^{8}$. Niels Finsen was a forerunner as to clinical photography in order to show the widespread and long-lasting skin manifestations caused by lupus vulgaris. Photos taken before and after treatment and in some cases even live patients were therefore part of the scientific presentations in Denmark and abroad, but surprisingly there is no information about the use of the wax moulages in this context. ${ }^{8}$

The collection found in 1978 consisted of 67 items, of which 52 were marked with year of production, diagnosis and the name of the patient. More than $50 \%$ of the labels have the diagnosis lupus vulgaris and an additional number showed other skin markers related to tuberculosis. Different skin diseases accounts for the rest of the diagnosis including three with syphilis.

The moulages were stowed away from 1978 until 1987 when the Light Institute merged with the dermatological department at Rigshospitalet. The then head of the Light Institute, made sure however, that certain effects including the moulages were donated and transferred to the Museum of Medical History (now Museion) in Copenhagen. A plan for a complete restoration and conservation was initiated and finalized in 2007 thanks to a private grant. ${ }^{9}$ All moulages have been photographed, cataloged and are now stored under conditions appropriate for the vulnerable wax material. Sixty-three moulages are online with photos and some information (in Danish). ${ }^{10}$ When first described ${ }^{5}$ there were related patient records, due to a homonym number at each moulage and the patient record. Unfortunately, all patient records were lost when the moulages were transferred from the Light Institute to Museion in 1987. The Finsen moulages do not have a permanent exhibition area at Museion, but have been in use for specific purposes. ${ }^{11-12}$

\section{DK-2. Bispebjerg Hospital Collection A.}

A collection of about 20 dermatological moulages moved from Rigshospitalet to Bispebjerg Hospital in 1996 when two dermato-venereological departments merged. The origin of this collection is unknown and questioning retired and former employees has not shown light on this.

Apart from three pieces, kept in an office room at the dermatological department, Bispebjerg Hospital, this collection, of which very few persons knew the existence, was stored in a remote basement room at the hospital. In April 2016, the hospital administration ordered a basement cleanup including discarding of unlabeled effects, unfortunately also the moulage collection stored without a contact name or phone number. The remaining three rather well preserved moulages have different looking paper labels indicating that different mouleurs were the artists. The labels have handwritten diagnosis and some information:

Xanthelasmatosis generalisata, Erythema induratum 1924, Leukemia cutis Dermatolog. Klinik Breslau. The wooden board of the latter has the signature of Alfons Kröner, a productive mouleur in Breslau from 1897 until his death in $1937 .^{2}$ The three remaining moulages have never been photographed, cataloged or evaluated by qualified persons. There is no plan for restauration, permanent storing or exhibition. They can be visited after personal appointment with the department staff.

\section{DK-3. Bispebjerg Hospital Collection B.}

A minor collection also transferred from Rigshospitalet to the dermatological department of Bispebjerg hospital in 1996 consists of six pieces made of another material than wax. These pieces are different from what is generally described as a moulage. However similar to seven pieces from the Würzburg collection originating from Deutsches Hygiene-Museum in Dresden being less sculptured than wax moulages, rather resembling photographs, and probably made by cellon/cellulose derivatives. ${ }^{2}$ Having six pieces in Denmark (one might have been lost) indicates that this collection are copies produced at the Deutsches HygieneMuseum in Dresden. The diagnoses (in German) are printed on the board, four depicting syphilis (one congenital), one ulcus molle and one tinea barbae. When and how they came to Denmark is unknown. There are no plans for these six pieces, being coincidentally saved and provisionally hanging in an office room at the department in Copenhagen were they could be seen after personal appointment with the department staff. For a 12 months period (2016-17), two pieces depicting syphilis and one with genital ulcers due to ulcus 
molle are part of an exhibition: 'Sex \& the Sea. Dreams, longing and the sex lives of sailors at the Maritime Museum of Denmark'. ${ }^{13}$

\section{Finland}

\section{FI-1. Ylppö's children}

Ylpön lapset (Ylppö's children) is a Finnish collection of paediatric wax moulages produced 1918-20 in Berlin by the German artist Anni Müllensiefen (1879-1927) ${ }^{14}$ in Kaiserin Auguste Victoria Haus Hospital ${ }^{15}$ where the Finnish paediatrician Arvo Ylppö (1887-1992) worked. Ylppö returned to Helsinki in 1920 for the chief position of the Children's Castle Hospital and for a professorship in paediatrics. ${ }^{16}$

In the beginning of the 1920s, Ylppö brought a collection of about 100 moulages to Finland. One third of the collection became part of a travelling exhibition aiming at educating common people about diseases and welfare for children less than 12 months. This exhibition, owned by a Finnish NGO (Mannerheim League for Child Welfare), was extremely popular in the 1920s and the early 1930s, actually shown in more than 200 municipalities and visited by 250.000 people during the first ten years. If not on the move, the exhibition was displayed in the Näsilinna building in Tampere. These moulages, gradually transferred to the Children's Castle Hospital, were in use until 1973 when educating childminders. Another third of the moulages collection, integrated in a museum in Helsinki, were reserved for teaching about child welfare and the remaining moulages for teaching medical students. ${ }^{4}$

Today 80 moulages are preserved and part of the Helsinki University Museum's collections. ${ }^{17}$ Thirty-five were donated by Ylppö himself in 1969, 13 were donated by the Finnish Paediatric Society in 1973 and the 32 moulages, exhibited at the Children's Castle Hospital were transferred in 2016.

The majority of the moulages depicts transmissible diseases such as syphilis, poxes, tuberculosis, rashes and umbilical disorders on faces, hands, torsos, feet and other infant body parts. Five moulages are prints of diapers and stools and a few depicts methods to diagnose or prevent diseases such as a Pirquet reaction and smallpox vaccination.

The attached paper labels are in Finnish, and for a few also in Swedish. Some have a diagnosis listed. There are duplicates with moulages portraying the same child, probably because it was the intention to divide the collection for use in different exhibitions and teaching purposes from the very beginning.

Over the years the moulages have quite often been exhibited; 23 moulages were exhibited in the Medical History Museum from 1970-2003 and thereafter in the Helsinki University Museum from 2003-2014. Some moulages have been part of temporary exhibitions with 13 moulages displayed in the pharmaceutical company Orion's exhibition “Arvo Ylppö 100” in 1987 and 5 moulages portraying smallpox and vaccination displayed in an exhibition about the history of vaccination in the Finnish Medical Convention and Meilahti Campus Library Terkko in 2012.

Today only one moulage is on display in a permanent exhibition "Power of Thought" in the Helsinki University Museum. However, a new exhibition 'Baby in the Box' scheduled for opening November 2017 will include some moulages, for which purpose, eight moulages underwent restoration. This exhibition will focuse upon the maternity package invented by the Mannerheim League for Child Welfare in the 1920s. Apart from that, there are no further plans for the use of Ylppö's children in the future, but it is likely that they will now and then show up in different exhibitions if relevant.

All Ylppö’s children have been photographed, catalogued and digitalized apart from a few being too damaged for correct registration. ${ }^{17}$ The conservation status of the 80 moulages differs depending on where and how they have been stored. White layer of crystallization of fatty acids covers especially thirteen moulages, exposed to moisture during WWII, whereas those being part of the child welfare exhibition in Helsinki and later displayed in the Children's Castle Hospital are in a better state. Thirteen moulages were included in a conservation survey from 2011 out of which three underwent a detailed and thorough restoration and conservation. ${ }^{4}$ 


\section{FI-2. Cologne moulages}

In 2013, Helsinki Vocational College donated nine moulages to the Helsinki University Museum. Each moulages had a printed label with the text "Universitätsklinik für Hautkrankheiten, Cöln Lindenburg" and the hand written signature "Sch. Hippolyta Augustinerin" carved on the wooden plate on which the moulage was mounted. According to the hand written diagnoses the moulages depicts various stages of Syphilis, Variola, Varicellen, Diphtheria and Angina follicularis.

The mouleur is Sister Hippolyta (1870-1962) a nun of the Augustinian order, who served more than 40 years as a nurse at the department of dermatology at the University Hospital in Cologne. ${ }^{18}$

Her birth name was Johanna Maria Wery, but in the order, she had the name 'Schwester Hippolyta'. Before entering the order in 1890, she produced religious wax figures in her hometown in the Eifel hills near Cologne. After World War I, she made prostheses for wounded soldiers by remodelling missing parts of the face. ${ }^{18}$ As far as it is known; Sister Hippolyta was the only one in her order that produced moulages. It is unknown where and how she received the artistic training and when she started the art of moulaging. The collection has been part of more than 1000 moulages made in the beginning of the $20^{\text {th }}$ century on request of Professor Ferdinand Zinsser (1865-1952) from the department of dermatology in Cologne. This department, founded in 1902, had the status of a university clinic from 1919 in accordance with the moulage labels: Universitätsklinik für Hautkrankheiten, Cöln Lindenburg. In Zinsser's book about syphilis 51 colour plates of moulages are quite similar to those in Helsinki ${ }^{19}$ and thus probably produced by Sister Hippolyta.

The Cologne moulages were used for teaching until colour photography replaced them. The majority of the moulages survived World War II. During the 1960s, however, in such a bad condition, being stored in a basement of the dermatology building, that the best thing was to forget them according to the then director of the clinic. ${ }^{20}$ The definitive loss and neglecting of the big moulage collection in Cologne happened in 1974 when the department moved and all remaining moulages were discarded. The nine moulages in Helsinki are thus the only left over Cologne moulages made by Sister Hippolyta between 1910-29. When and how they came to Finland is an unanswered question even when asking the Helsinki Vocational College where the moulages were stored for many years. None of the moulages have been exhibited, many are damaged and with fractures. They have been photographed and catalogued and seven are digitalized with some information. ${ }^{21}$ There are no plans for restoration or conservation.

\section{FI-3. Panoptikon}

Twenty-eight moulages mounted in showcases, depicting infectious and dermatological skin diseases have had an itinerant life all over Europe as part of a Panoptikon. The latest owners, the Finnish artists Wäinö Hamari and Esa Karttunen, bought the collection in 1989. The last exhibition was in Estonia in 2007. Fourteen moulages are still in Finland under the care of Wäinö Hamari, whereas Esa Karttunen sold his part to the Deutsches Hygiene-Museum in Dresden in 2009. The condition of the 14 moulages in Finland varies. Most of them are relative well preserved, one is broken and some with cracks. The majority has a label with a diagnosis. None of them have been restored, photographed or catalogued. In contrast, those sold to the Deutsches Hygiene-Museum in Dresden have been through a thorough conservation and restoration phase. ${ }^{22}$ According to recent information from the Deutsches Hygiene-Museum in Dresden, all these moulages are copies produced for sale in the beginning of $20^{\text {th }}$ century. The wellknown mouleur Fritz Kolbow (18731946) ${ }^{2}$ who took part in the establishment of the museum in Dresden between 1910 and 1918, made the original models. The moulages in Finland are not on display. Loans and/or inspection is however possible after direct contact with the owner. The moulages now in Dresden were part of the "Blicke! Körper! Sensationen! Ein anatomisches Wachskabinett und die Kunst" exhibition in 2014-15. ${ }^{22}$ 
NO-1. The Leprosy Museum/Bergen City Museum

Bergen city, the former epicentre of leprosy, has had a leprosy Museum since $1970 .{ }^{23}$ The old buildings of St. George's Hospital, a former leprosy hospital that closed down when the last patient died in 1946, is housing the museum. Thirty-one wax moulages depicting skin lesions and disfigurements typical for the disease leprosy are stored in the museum. Since 2003, two faces and three hands mounted in glass-covered boxes have been part of the permanent exhibition, whereas the remaining 26 moulages are unavailable for the public. Most of the moulages shows sign of aging.

None of the Bergen moulages have a diagnosis attached most likely because they all depicts leprosy and thus had a given diagnosis. Twenty-three moulages of faces and limbs are mounted on wooden boards to be hung on the wall while eight moulages of hands and feet, are mounted in an upright position. The Bergen moulages differs as to the art of moulaging indicating different mouleurs.

Five moulages has the inscription '1913' and a signature that looks like the letters 'RAE' on the wooden board, but no further information about the production place or the mouleur. Eight moulages depicting hands and feet have neither information as to the year of production nor to the name of the mouleur. There is no information about how and when any of these 13 moulages came to Bergen.

A cabinet with the inscription: "Present from Oscar Lassar, Berlin" holds a collection of 18 moulages but without information about the mouleur or the year of production. The German dermatologist Oscar Lassar (1849-1907) founded a moulage collection at his private skin clinic in Berlin just after the First International Congress of Dermatology and Syphilology in Paris in 1889, with the aid of his mouleur Heinrich Kasten (1842-1921). ${ }^{2}$ Lassar bequeathed about one-thousand moulages to the Kaiserin-Friedrich Hospital in Berlin. The collection was donated to the General Hospital in Hamburg after his death in $1907 .{ }^{2}$

Bergen had three hospitals treating the largest number of leprosy patients in Europe between 1850 and 1900. Dr Daniel Cornelius Danielssen (1815-1894) made Bergen a world center for leprosy research and published the famous book 'Om Spedalskhed'(On leprosy) ${ }^{24}$ in 1847 together with Carl Wilhelm Boeck (1808-1875), followed by a folio atlas with 24 executed lithographed plates in colour, drawn by Johan Ludvig Losting (1810-1876). ${ }^{25}$

Leprosy was at that time classified as a skin disease until the identification of Mycobacterium leprae in 1873 by Danielssen's son-in-law Gerhard Armauer Hansen (1841-1912). ${ }^{26}$ Danielssen and Hansen won worldwide recognition as leading specialists on leprosy, with a wide network of contacts among doctors and scientists, including Oscar Lassar. Hansen and Lassar were vice presidents at the First International Leprosy Conference in Berlin in 1897. Lassar visited Bergen at least twice: in 1895, in order to unveil a memorial plaque over Dr Danielssen ${ }^{27}$ but that was before his mouleur, Heinrich Kasten (1842-1921) started the moulage production in Berlin, and again in 1901 as keynote speaker at the unveiling of a bust of Dr. Gerhard Armauer Hansen. ${ }^{28}$ It seems reasonable to suggest that Lassar honoured his colleagues in Bergen by donating a collection of dermatological wax moulages, produced in Berlin, depicting skin manifestations of leprosy in connection to or shortly after his visit in 1901. It is a bit noteworthy however that they lack the linen surrounding the moulage, usually seen on those made by Heinrich Kasten ${ }^{2}$ a finish also described by the Greek physician G Photinos (1876-1958), who learned the art of moulaging in Kasten's studio. ${ }^{29}$ There are no information as to the use of the German leprosy moulages in Bergen nor to the patents behind, in contrast to the Norwegian patients pictured in the atlas on leprosy by Losting. ${ }^{25}$

The moulages in Bergen have been neither photographed, nor restored and there are no current plans for this.

\section{NO-2. The National Medical Museum, Oslo}

The National Medical Museum in Oslo, established as a part of the Norwegian Museum of Science and Technology ${ }^{30}$ in 2001, stores a small collection of six moulages, hitherto kept at different folk schools and at Akershus Fylkesmuseum. This collection depicts infectious diseases in small children. The diagnoses (Scwämmen/Soor in der Mundhühle, Masern/Morbilli, Scharlach/Scarlatini, Diptherie, Windpocken/ Varicellae, Pocken/Variola), written on labels indicate that the moulages originates from Germany. It is striking how similar they are to the above described Finnish collection 'Ylppö's children“ made by Anni 
Müllensiefen in Berlin after 1910, not in disagreement with the fact that the collection in Oslo was in use in 1916 as part of a well-known exhibition about childbirth and poverty 'Barselhjemsutstillingen'. This exhibition was initiated by Katti Anker Möller (1868-1945) ${ }^{31}$ and visited many Norwegian cities in 1916-17. The moulages in Oslo have been photographed and digitalized ${ }^{32}$ but there are no plans for restoring them.

Sweden

\section{SE-1. Museum of the History of Medicine, Stockholm}

The largest collection of dermatological moulages in Sweden is currently stored in the warehouse of Stockholm's Museum of the History of Medicine (closed in 2005, but the collections remain). Out of the 330 moulages in the collection, many suffers from being displayed and stored in bad environments over the years, but some are still in excellent condition. These moulages were made from the 1890s to the 1920s, judging from inventories and notes on some of the labels. The original catalogs have been lost, but it seems like the moulages came to the museum from two main sources: Karolinska Institutet and S:t Göran's Hospital in Stockholm. All moulages are mounted in the classic way, on a black wooden board, with the moulage wrapped in white cloth. Most are numbered and supplied with hand-written labels stating the diagnoses.

A large group of these moulages was made at the Pathoplastisches Institut in Berlin. Fritz Kolbow signed some of them. Kolbow, who collaborated with Rudolph Virchow and the Deutsche Hygiene Museum in Dresden, was admired for making moulages so realistic that they could be taken for real body parts. ${ }^{2,33}$ Many of these are from the early 1900s, but there are also a few from Kolbow's post-WWI operation, labeled "Atelier für medizinische Lehrmittel, Berlin N.W." in the upper left corner. Smaller numbers of moulages were made at the Charité hospital in Berlin, by the Viennese father and son Henning, and by Von Johnsen in Freiburg. ${ }^{2}$ One moulage that stands out in its exquisite attention to details was made by the masterful Beretta, at the Hôpital St Louis in Paris. ${ }^{2,33}$ The label states that it represents "Pitiryasis rubra pilaire (Maladie de Devergie)" of the left hand.

It is not possible to say how many of the unmarked moulages that were produced locally. Two Swedish artists appear by name, Evy Björling and someone who appears by the name Nelken. Evy Björling (18431947) was married to Emanuel Björling (1869-1939) ${ }^{34}$ who worked at the clinic of venereal and dermatological diseases in Malmö from 1910. So far, nothing is known about Evy Björling's training or how her moulages ended up in the collections in Stockholm, but it seems likely that she worked alongside her husband, producing moulages representing cases at the Malmö clinic. Björling's work in the Stockholm collections covers a variety of syphilitic lesions as well as conditions such as psoriasis, ecthyma, and partial albinismus. Her signature resembles those of other moulage artists, painted in white next to the cast on the lower right hand side.

The artist "'Dr. M. Nelken fecit" appears on a few labels together with a "Dr. Almkvist." It has not been possible to figure out who Nelken was, but Johan Almkvist (1869-1945) ${ }^{35}$ was professor of syphilodology and dermatology at Karolinska Institutet from 1913, as well as a leading specialist at S:t Göran's hospital in Stockholm. S:t Göran's opened in 1888, and its clinic for venereal diseases functioned as teaching clinic for students from Karolinska Institutet. Edvard Welander (1846-1917), Almkvist's predecessor, obtained funding from Karolinska Institutet and the Swedish parliament in 1904 and 1908 in order to purchase moulages as teaching tools, to make up for a lack of sufficient numbers of patients at the clinic. By 1911, the clinic had acquired 135 moulages ${ }^{36,37}$ An article from 1988 claims that the moulages might have belonged to the Swedish Finsen Institute, situated at S:t Göran's hospital 1901-1986. ${ }^{38}$

\section{SE-2. Private Collection, Stockholm}

Another interesting cache of waxes belongs to a private collector in the Stockholm area. It was once displayed next to the Gröna Lund fairground in Lütze's Panoptikon, which closed down in the 1920s. Its models and moulages came from several of the well-known European traveling wax shows, such as Castan's 
Panoptikon. Many moulages in this collection depict venereal diseases in the same style as the teaching moulages. The three-dimensional genitals were on display in a separate room, shown only to adults for an extra fee. Ladies were welcome on Wednesday afternoons. These moulages very much resemble the ones in medical museums, but the display context alters their cultural meaning: at Lütze's Panoptikon they became at once a titillating attraction and a moralizing warning against a sinful way of life. Moulages and models from this collection have recently been displayed in temporary exhibitions at the National Museum of Fine Arts and the National History Museum in Stockholm, but their current condition is unknown. ${ }^{39,40}$

\section{SE-3. Medical History Society, Västerås}

The medical history society "Westmannia"41 owns seven moulages depicting syphilitic lesions of the face and buttocks. Three of these are currently on display at the regional hospital of Västerås. Fritz Kolbow manufactured at least one of these. The hand-written labels strongly resemble the ones in the Stockholm museum collection, and it is very likely that these moulages were brought to Västerås from S:t Göran's Hospital or Karolinska Institutet in Stockholm.

\section{SE-4. Medical History Museum, Umeå}

The medical history museum in Umeå ${ }^{42}$ owns eight dermatological waxes, which are currently on display, mounted in glass-covered boxes and in good condition. Two of these were made at the Deutsche Hygiene Museum in Dresden, the others are marked "MULAZAC-ZAGREB, ULICA, S MAJU, 1945." Interestingly, only one of them represents syphilis. The origin of these moulages is unclear, but some of them seem to have been donated to the museum from the local nursing school, which bought them as late as in the 1960s. The fact that they are mounted in boxes probably indicates that they have once belonged to a traveling wax exhibition.

\section{Discussion}

This paper presents a detailed overview as to the present situation about dermatological moulages collections in the Nordic countries. Hitherto undescribed collections are presented together with updated information about those previously known. There are no moulages collections in Iceland, the Faroe Islands, Åland Islands or Greenland. Sweden has the highest number of known moulages, most of them in Stockholm. The Nordic moulages seems to have been collected locally and without any exchange between the Nordic countries.

The reason for having moulages are multifaceted. Teaching medical personal about common as well as rare diseases was one of the main issues from the very beginning in the late $19^{\text {th }}$ century. At that time, travelling from one dermatological department to another within and especially outside a country in order to attend meetings with patient presentation must have been limited to selected staff members. For this reason, moulages with their extremely detailed presentation of all the visible aspects of skin diseases in a threedimensional way could facilitate the difficult presentation of diseased skin.

Visual context is a cornerstone in medical education not least in dermatology. Photography and drawings have their limitations, but have had an important place also in the Nordic countries. Niels Finsen and his staff presented the convincing effect of their light treatment in black-white photos showing facial lupus vulgaris before and after treatment at a world conference in Paris in $1900 .{ }^{8}$ Drawings in color was an important way of visualizing skin diseases with the eminent atlas about leprosy by the Norwegian artist J.L Losting as a well-known example. ${ }^{25}$

At a time where the art of dermatological moulages production flourished in the middle and southern European countries, there seems to have been a limited production and rather few imported collections in the Nordic countries. The reason for this was not the lack of scientific societies for dermato-venereology, 
established around 1900 in all the Nordic countries. From 1910 also as a Nordic Dermatology Association with the object to: 'Promote Nordic cooperation in scientific, educational and clinical aspects of dermatology and venereology'. ${ }^{43}$ Presentation of interesting cases and therapy dominated the discussion at these meetings, however without any leftover information about the presentation or use of moulages. Economy could however be a limiting factor. Moulage production is not only expensive and time consuming it also demands a skilled mouleur trained in visualizing the essential markers of the specific skin disease. A trained mouleur needs 3-4 hours for moulaging a face with disseminated eruptions due to lupus vulgaris or acne vulgaris. ${ }^{29}$

Professor Lassar in Berlin and his mouleur Heinich Kasten had an open-minded attitude as to passing on details about the art of moulaging. ${ }^{2}$ If already educated in dermatology and thus familiar with the many details present in a skin disease the art of moulaging could be captured in a month, if untrained a much longer introduction was needed. ${ }^{29}$ There were many courses at Lassar's clinc for doctors trained in dermatology. In contrast, other European dermatological clinics with some of the most respected mouleurs were reluctant in giving any details about the preparation of the plaster, the wax mixture, colouring methods and refinement, an attitude reported for Joseph Towne (1806-1879) from London and especially for the famous French mouleur Jules Baretta (1833-1923). ${ }^{2}$

\section{The mouleur}

In the Nordic countries, only Denmark and Sweden seems to have had a local moulage production.

\section{Denmark}

There are no signature on any of the Finsen moulage. This is in contrast to what was common all over Europe where the written signature of the mouleur was an important marker before a moulage was considered ready for use. However, there is no reason to mistrust the information about Theodor Edelmann, the mouleur from the Finsen Institute whose portraiture background gave him a detailed knowledge about wax and its use in visualizing human skin. Furthermore, Edelmann could very well have been introduced to the art of moulaging in Vienna in the early 1890s where Carl Henning (1860-1917), a physician and medical illustrator started his famous moulage production, and in 1892 when Henning presented his work at the $2^{\text {nd }}$ International Congress of Dermatology and Syphilology in Vienna., 244

We know from the lost patient records from the Finsen Institute that 'mouleur' was now and then a prescription in the record maybe indicating that moulaging was a function at the Institute and not necessarily a specific person. Being highly skilled for introducing the time consuming moulaging, T Edelmann might have initiated and supervised the process with assistants for part of it, explaining the lack of a signature on each item. However, without signature the Finsen moulages are alike as to the wax material used, the coloring and the mounting on a black wooden board thus compatible with having the same production place and one mouleur or at least one responsible artist.

\section{Sweden}

Some of the moulages from the Stockholm collection have a written signature on the board. Two names indicate that there was a local moulage production in Sweden.

One signature is that of Evy Björling who married Emanuel Björling and gave birth to six children between 1893 and 1914. Emanuel Björling was authorized doctor at the clinic for venereology and dermatology in Malmö. ${ }^{34}$ The moulages with the signature of Evy Björling may thus depict patients from her husband's clinic. How and when she learned this time consuming artistic expression is however unknown.

It is also unknown when and how these moulages ended up in Stockholm. Was it commissioned work, a gift or were they just later transferred as museum objects? 
The other mouleur from Sweden, about whom there is even less information, only appear with the name Nelken on a few moulage labels, thus without disclosing if the name belongs to a man or a woman. These labels also mention a link to Johan Almkvist, a well-known dermato-venereologist, professor in syfilidologi in 1912, and professor at Karolinska Institutet 1913-1934. ${ }^{38}$ Almkvist authored numerous scientific publications of mainly syphilidological, serological and dermatologically content. In 1920, he founded Acta Dermato-Venereologica, an international peer-reviewed journal for clinical and experimental research in the field of dermatology and venereology. It is likely, then, that Almkvist continued collecting moulages at the teaching clinic at St Göran's hospital, which his predecessor Edward Welander started in 1904 by purchasing objects for a teaching collection. ${ }^{36,37}$

\section{Other mouleurs}

Apart from six Swedish moulages in Umeå, originating from Zagreb, Yugoslavia, and one single French Baretta moulage in Stockholmit it is notable that German artists seems to be the manufacturers of all other Nordic moulages. Scandinavian physicians and scientist had historically close relations to medical and scientific institutions in Germany until the 1930s. This, together with the fact that Germany had a number of prominent manufacturers of wax models and moulages, probably explains why so many of the moulages in the collections came from Germany.

Each item in the Finnish Ylppö collection have been casted by, Anni Müllensiefen a painter and artist connected to Kaiserin Auguste Victoria Haus ${ }^{14}$, a hospital in Charlottenburg-Berlin dedicated to children welfare and focusing upon the high infant mortality after infectious diseases. There are no information about where Anni Müllensiefen learned the art of moulaging, though a fact that highly skilled production places and even courses in moulaging where at hand in Berlin at that time. The exact production period and the total number of items made by Anni Müllensifen is unknown. Ylppö's children seems to be what is left of her production.

Another German artist is sister Hippolyta using the signature 'Sch Hippolyta Augustinerin', the manufacturer of the nine Finnish Cologne moulages. ${ }^{18}$ Sister Hippolyta was a productive person not only making dermatological moulages but also prosthesis for wounded soldiers. ${ }^{18}$ Cologne was at that time relative far from the most prominent German moulages workshops in Breslau, Berlin and Dresden, so one might consider whether she was self-taught. However having her daily work at a dermatological department gave her an eminent advantage as to the study and knowledge about the diseased skin. Many of the well-known German production places had moulages for sale. If not bought the Nordic moulages from other German manufacturers may be gifts. The fact that 18 moulages in Bergen was stored in a cabinet with the inscription 'Present from Oscar Lassar, Berlin' certifies this together with the openminded attitude as to the popularization of moulaging that prevailed in Berlin. In contrast, Alfons Kröner, the manufacturer of more than thousand dermatological moulages in Breslau, was reluctant to share his knowledge. ${ }^{2}$ One Kröner moulage ended up in Copenhagen, whether bought or donated is however unknown.

Another well-known German mouleur to whom some of the Nordic moulages bears relation to is Fritz Kolbow. A Finnish collection of 28 pieces, half of which are still in Finland whereas the Deutsches Hygiene-Museum in Dresden bought the other half in 2009, originates from Dresden. These moulages are all copies. Fritz Kolbow, who worked most of his life in Dresden, made the originals in the first decades of the last century. Moulage production including copies for sale continued for many years at the Deutsches Hygiene-Museum in Dresden also after the WWll, however laid down after the reunification of Germany as a cost-intensive production. ${ }^{2}$ Considerable parts of the Nordic moulages are of unknown origin, though in some cases the diagnoses on the labels indicate that they came from Germany. 
For some of the Nordic collections the diagnoses reflect the prevailing diseases where they were produced/stored such as: lupus vulgaris at the Finsen Institute (Fig 1), leprosy in Bergen (Fig 2), and communicable diseases at a children's hospital in Helsinki (Fig 3). Apart from that, the diagnoses should not be considered representative for disease prevalences at that time as one of the issues when building up a moulage collection, was the ability to present cases for teaching otherwise seldom in live patients. The collections in Sweden holds several moulages depicting syphilis (Fig 4). The majority with this diagnosis reflects not only the high prevalence of syphilis and other venereal diseases before and after WWI but also the medical profession of the specialized collectors working at clinics specifically treating patients with venereal diseases in Malmö (Emanuel Björling) and in Stockholm (Johan Almkvist). A forerunner in Sweden as to the introduction of venereal moulages for teaching was Edward Welander, a syphilis specialist who obtained financial support from the state for the purchase of venereal moulages as teaching tools in the first decade of the nineteenth century. ${ }^{36,37}$ As to the battle against syphilis Welander is especially known for the initiative of opening the first 'Welander home' in 1900 in Stockholm and later elsewhere in Sweden, Denmark, Finland and Norway ${ }^{45,46}$ dedicated for the care of pregnant syphilitic women and for the treatment of congenital syphilis.

The moulages from Helsinki depicting infectious diseases in children have been in use for teaching as long as up to 1973, but otherwise it is rather unknown to what extent and for how many years the Nordic collections have had a teaching issue for medical staff. For the general population however, the public health issue was prominent in many European countries, aiming at behaviour changes, and thus an incident decrease when demonstrating the consequences of communicable diseases visualized by the moulages. The realistic presentation of severe clinical symptoms and sequelae with the aid of wax moulages were especially welcome in the fight against sexually transmittable diseases. In 1907, Photinos, educated at Lassar's studio in Berlin, wrote: 'Venereal moulage collections will advise the public, as scientific information and public health education is the only way to lower the number of venereal diseases'. ${ }^{29}$ In Denmark, three venereal moulages from the DK-2 collection are on display at the Maritime Museum in Helsinore in 2016-17 in a separate exhibition forcusing upon 'Sex and the Sea'. ${ }^{13}$ This is the one and only known use of Danish venereal moulages related to public health though in this case only as a historical admonition and a raised index finger about the consequences of unsafe sex resulting in the acquisition of a disease at that time untreatable.

The public health aspect is quite clear for Ylppö's children travelling all over Finland as part of an exhibition focusing upon children's well fare. The public health aspect of a collection integrated in a Panopticon/wax cabinet may however have been more diverse.

In Germany, the public health aspect was the prevailing aim for the moulage production at the Deutsches Hygiene-Museum, a communicator of public health information, also under shifting political systems during WW1l and the DDR period. The museum in Dresden, restored during the last decades, still stands as a cultural institution of national importance. ${ }^{22}$ The wax moulages have furthermore regained their importance as teaching aids for the introduction to dermatological training in certain museums. ${ }^{47}$ Moulages often depicts the disfigured body especially the faces as seen in Fig.1, a wax cast of a 15-year-old boy with lupus vulgaris. The social consequences for these patients must have been unbearable often leading to exclusion from families and work. For those treated at the Finsen Institute presentation before and after successful treatment for lupus vulgaris might have had an effect in allocating people hiding their disfigured faces to stay forward for treatment, being free of charge for those who could not afford it. ${ }^{8}$

During the first decades after WWll moulages lost their position as teaching and visual aids in most European countries where after the mouleurs and hence the expertise disappeared. Collections were stowed away, often in inappropriate rooms leading to a gradually decline. ${ }^{48}$ 
Some of the Nordic moulage collections are digitalized, and thus at least preserved and visualized in this way though without the three dimensional impact: DK- $1^{10}$, FI- $1^{17}$, FI- $2^{21}$, NO- $2^{31}$, SE-1, whereas this is not the case for DK-2, DK-3, FI-3, NO-1, SE-2, SE-3, SE-4.

Many European moulage collections have been digitalized; some of them are listed in a German archive. ${ }^{3}$ The intention of this archive is to build up information about existing collections, together with information about the condition, availability, year of production and previous use. The only Nordic collection mentioned in the German archive is Ylppös children. ${ }^{3,17}$ In 2009 the Dresden group took the initiative of arranging an International conference ${ }^{49}$ devoted to: 'Interdisciplinary communication on the aesthetic, historical and physical properties of moulages...permit an exchange on the use, study, conservation and restoration of the moulage collections still extant throughout the world''. The aim of the conference was to bring together custodians of moulage collections, medical scientists, medical historians, conservators/restorers, conservation scientists and museologists as well as cultural scientists and curators, and to establish the first general standards and guidelines for the future conservation of moulages. Details and results about the restoration and conservation of the Finsen moulages were presented. ${ }^{9,49}$ The expertise for restoration and conservation is also at hand in Finland having restored some of Ylppö's children. Apart from that, the majority of the Nordic moulages are in need of restoration and conservation in order to hinder further decay. The existence of expertise is a prerequisite, but it is extremely difficult to implement this time consuming and expensive process without specific donations. The enclosed data have updated our knowledge about existing moulage collections in the Nordic countries. In order to secure data for the future each country have been encouraged to share their information with the German archive ${ }^{3}$ and henceforth to correct and extend the information if further data should be revealed.

\section{Acknowledgements}

The collection of data for this manuscript would not have been possible without inestimable help especially from the persons listed below. For further information, please contact the author from the relevant country.

Denmark: Bo Lasthein Andersen, Flemming Brandrup, Erik Løytved, Tove Agner, Jørgen Serup, Gudrun Agnarsdottir

Norway: Ellen Lange

Finland: Wainö Hamari, Axel Karenberg, Tarja Tomminen, Julia Radtke

Sweden: Jan-Olof Brånstad, Björn Wiklund, Margarethe Bylander, Hans K:son Blomquist,

\section{References:}

1. Wallach D, Tillès G. First International Congress of Dermatology and Syphilology, Paris, Aug. 510, 1889. J Am Acad Dermatol 1992; 26: 995-1001.

2. Schnalke T. Diseases in Wax: the History of the Medical Moulages. Quintessence Publishing Co, Inc, Berlin, Germany, 1995.

3. Archiv für medizinische Wachsbilder (Moulagen). Available at: http://www.moulagen.de/sammlungen (last accessed 30 September 2017).

4. Haavisto E. Ylpön lapset:Vuosina 1918-1920 valmistettujen vahakuvien esinehistoria ja konservointi. Available at: http://www.theseus.fi/handle/10024/44564 (last accessed 30 September 2017).

5. Andersen BL, Brandrup F, Wantzin G. Moulage-samlingen på Finsens Medicinske Lysinstitut. Medicinsk forum 1982; 34: 149-53. 
6. Weilbachs Kunstnerleksikon. Available at: http://www.rosekamp.dk/Weilweb/index2.html (+E, + Edelmann) (last accessed 30 September 2017).

7. Finsen NR. The Nobel Prize in Physiology or Medicine 1903. Available at: www.nobelprize.org/nobel_prizes/medicine/laureates/1903 (last accessed 30 September 2017).

8. Lyngbye J. Lyssagen - Niels Finsen og hans team på Finseninstituttet. Copenhagen: Gyldendal, 2003.

9. Meyer I. Bevaringsplan for de danske moulager. In: Arsskrift for Medicinsk Museion. (Mordhorst C ed.), 2004; 1: 32-9.

10. Voksmoulager fra Finsens Medicinske Lysinstitut. 2010. Available at: https://www.kulturarv.dk/mussam/VisSag.action;jsessionid=43420521DE7C1A5CE4E335FA98BA FC3F?sagId=613511(last accessed 30 September 2017).

11. Howaldt N.: Light Break. Photography/light Therapy, ISBN 978-87-998207-0-2, Fabrik Books, 2015.

12. Dermatological history Symposium: Towards the light. EADV, Copenhagen, October 10, 2015. Available at: https://user-cc0betr.cld.bz/Final-Programme-24th-EADV-CongressCopenhagen\#101/z (last accessed 30 September 2017).

13. Maritime Museum of Denmark. Sex \& the Sea. Available at: http://mfs.dk/en/exhibition/sex-the-sea (last accessed 30 September 2017).

14. von Borries E, von Borries E. Anni Müllensiefen 1879-1927:Ein Leben zwischen Familie, Kunst und Wissenschaft: München:Arethousa, 2015.

15. Kosenow W. Kaiserin-Auguste-Victoria-Haus--an institution at the crossroads? (Article in German) Kinderkrankenschwester 1995; 14: 171-174.

16. National Biography of Finland. Ylppö A. Available (in Finnish) at: http://www.kansallisbiografia.fi/kb/artikkeli/6543/(last accessed 30 September 2017).

17. Finnish Archives. Available at: http://www.finna.fi (+ylpön +lapset +moulage) (last accessed 30 September 2017).

18. Hoffmann KJ. Schwester Hippolyta Wery und Schwester Honorata Feuser. Aus dem Leben zweier Ordensfrauen aus Großbüllesheim. Jahrbuch Kreis Euskirchen 2009; 81-82.

19. Zinsser F, Stein JB. Diseases of the Mouth: For Physicians, Dentists, Medical and Dental Students. New York, Rebman, 1912.

20. Steigleder GK. Zur Geschichte der Universitäts-Hautklinik Köln. Der Hautartz 1977; 28 (suppl. II): XV-XIX.

21. Finnish Archives. Available at: www.finna.fi (+moulage $+201398 a)$ (last accessed 30 September 2017).

22. Meyer-Hermann E. Blicke! Körper! Sensationen!: Ein Anatomisches Wachskabinett und die Kunst. Deutsches Hygiene-Museum Dresden, 2013.

23. Lepramuseet. Available at: http:// www.bymuseet.no/vaare-museer/lepramuseet (last accessed 30 September 2017).

24. Danielsen DC, Boeck CW. Om spedalskhed. Norway: Christiania, 1847.

25. Danielsen DC, Boeck CW. Atlas Colorié de Spedalskhed. Norway: Prahls Lithographs, Bergen, 1847.

26. Jay V. The legacy of Armauer Hansen. Arch Pathol Lab Med 2000; 124: 496-497.

27. Melsom R. Pleiestiftelsen for spedalske Nr.1, 1857-1957. Tidsskr Nor Laegeforen 1957; 77: 414.

28. Beyer H. Fra Christie til Nordahl Grieg: XIII Bergenske kulturpersonligheter. Norway: Bergen, 1945.

29. Photinos G.: Die Herstellung und Bedeutung der Moulagen (farbige Wachsabdrücke). Dermatologische Zeitschrift 1907;14:131-157.

30. Norsk Teknisk Museum. Available at: http://www.tekniskmuseum.no (last accessed 30 September 2017). 
31. Katti Anker Møller. Available at: https://historie2.wikispaces.com/Katty+Anker+Møller (last accessed 30 September 2017).

32. Digitalt Museum. Available at: http://digitaltmuseum.no. (+Krankheiten in Säuglings und Kindesalter) (last accessed 30 September 2017).

33. Parish LC, Worden G, Witkowski JA, Scholz A, Parish DH. Wax Models in Dermatology. Trans Stud Coll Physicians Phila 1991; 13: 29-74.

34. Bjørling HE. Available at: http://www.bjorling.org/ansedlar/flock2/002/00/155.php (last accessed 30 September 2017).

35. Schöldström U.: Professor och nudismens förespråkare; Läkertidningen 2010;107: 2668.

36. Åhrén E. Museerna: Vetenskap i tre dimensioner. In: Medicinen blir till vetenskap: Karolinska

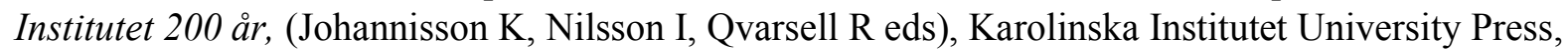
2010; 126-169.

37. Welander E. Syfilidologiska kliniken. In: Karolinska medico-kirurgiska institutets historia, Vol.3. (Edgren JG, Lennmalm F, Jolin S eds) Stockholm,1910.

38. Diener L. Anatomiska och patologiska figurer och modeler-från votivgåvor till hjälpmedel vid undervisning. In: Nordisk medicinhistorisk årsbok.1988; 131-34.

39. Åhrén E. Känn dig själv: Om vaxkabinett och anatomiska utställningar. In: Den mediala vetenskapen. (Ekström A ed.), Nora: Nya Doxa, 2004.

40. Åhrén E. Kroppar av vax: Modeller och preparat i konst och vetenskap. In: Kroppen: Konst och vetenskap. (Holger L ed.), Stockholm, 2005.

41. Medicinhistoriska Sällskabet Westmannia. Available at: http://www.msw.org.se/History.htm (last accessed 30 September 2017).

42. The Historical Museum of Medicine in Umeå. Available at: https:/www.acc.umu.se/ saasha/ubicomp/ (last accessed 30 September 2017).

43. Nordic Dermatology Association. Available at:http://www.nordicdermatology.com (last accessed 30 September 2017).

44. Joshi R. Moulages in dermatology-venereology. Indian J Dermatol Venereol Leprol 2010: 76: 434438.

45. Hollstrom E. A follow-up study of the results of treatment in children with congenital syphilis at the Welander Home, Stockholm, between 1900 and 1950. Acta Derm Venereol Suppl (Stockh)1950; 31: 89-95.

46. Jørgensen OS. The »Welander Home« on Bispebjerg Bakke. Bibl Laeger 2008; 200: 467-472.

47. Parish LC, Geiges ML. The wax model, Skinmed 2011; 9: 275-277.

48. Sticherling M, Euler U. Das „Sterben” der Moulagen - Wachsabbildungen in der Dermatologie, Hautarzt. 1999; 50: 674-678.

49. Morbid Anatomy. Available at: http://morbidanatomy.blogspot.dk/2009/08/conference-waxmoulages-as-cultural.html_(last accessed 30 September 2017). 


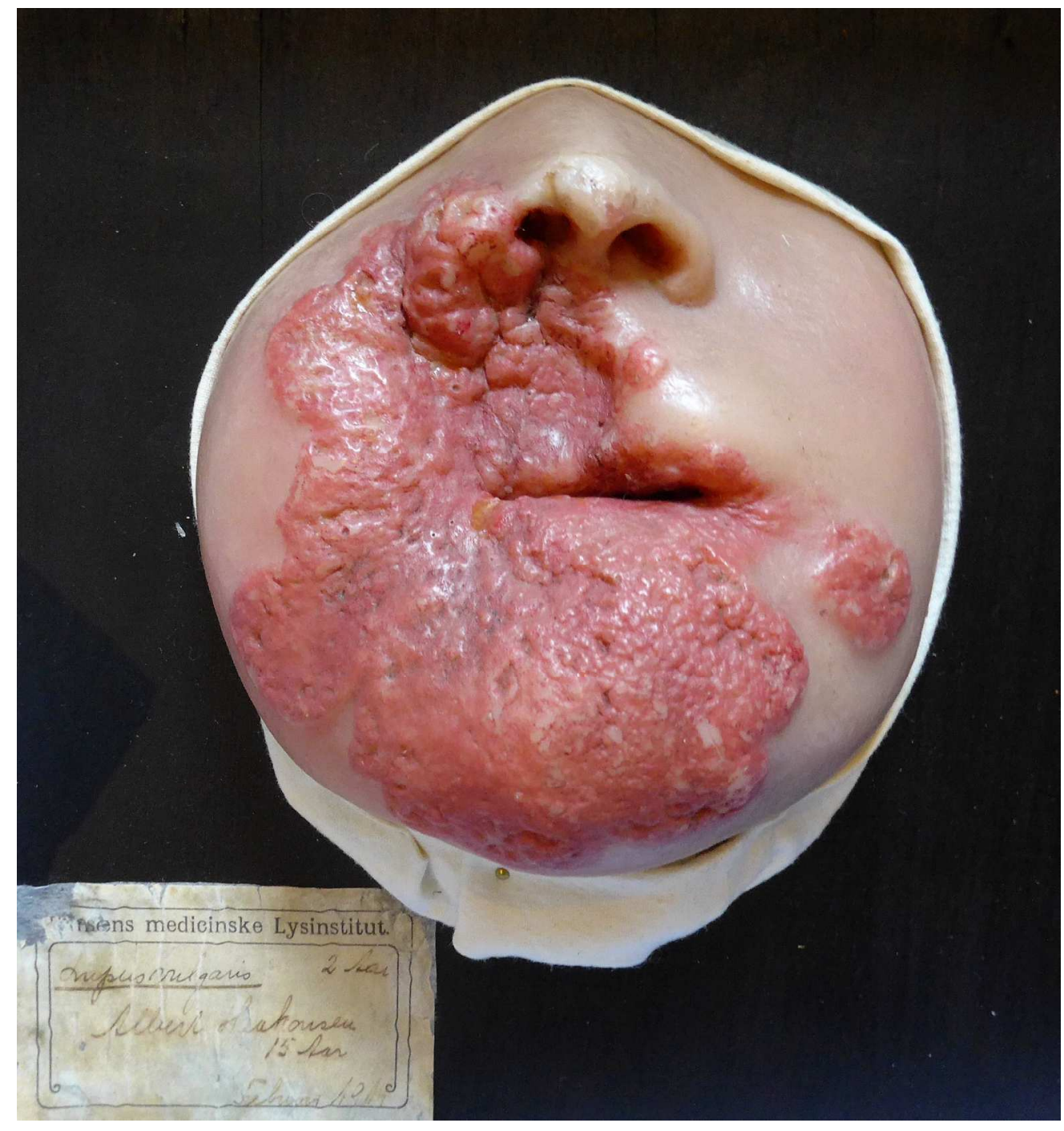

Lupus vulgaris, DK-1 collection $318 \times 339 m m(180 \times 180$ DPI $)$ 


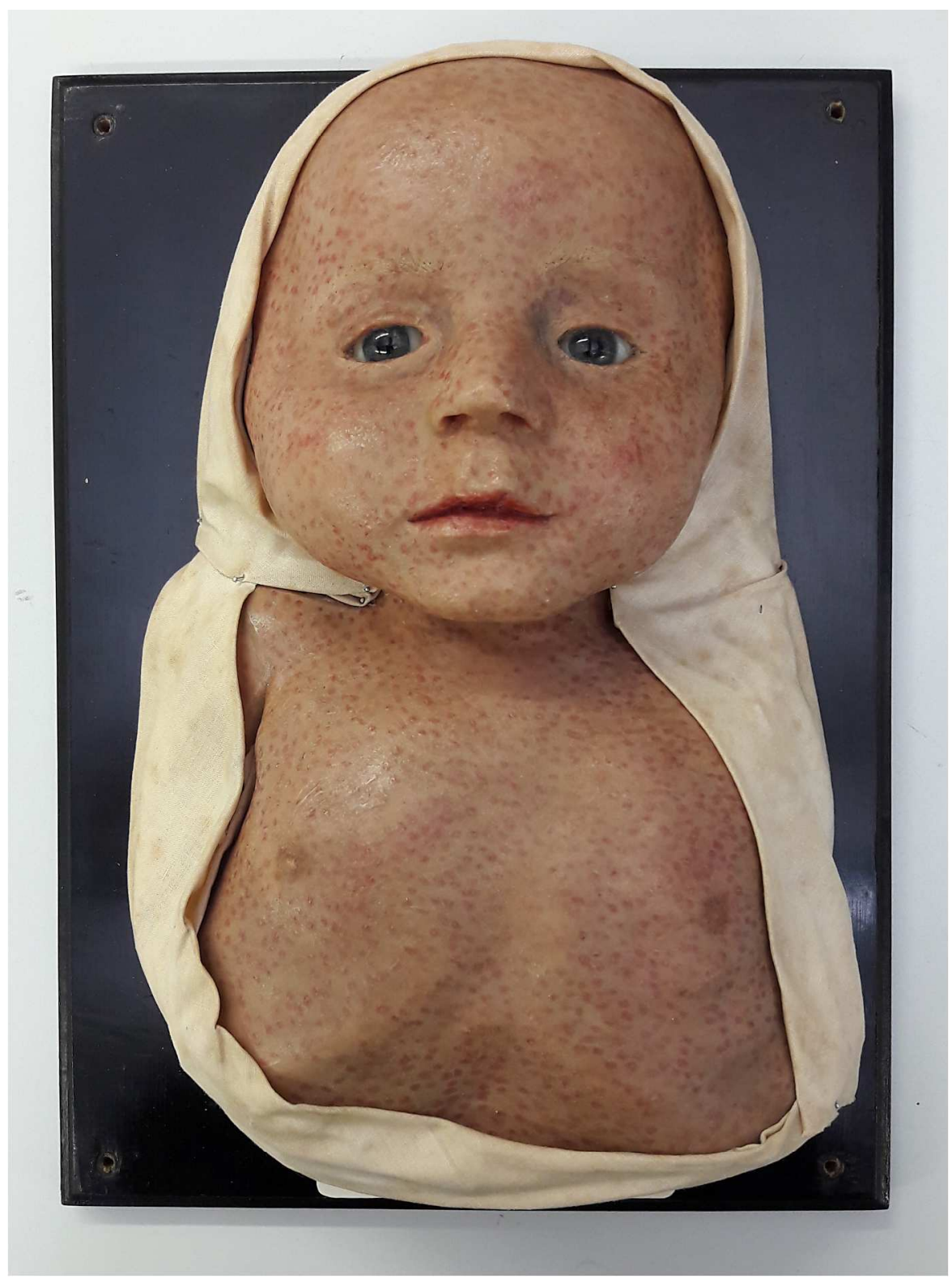

Rubella, FI-1 collection $806 \times 1083 \mathrm{~mm}(72 \times 72$ DPI $)$ 


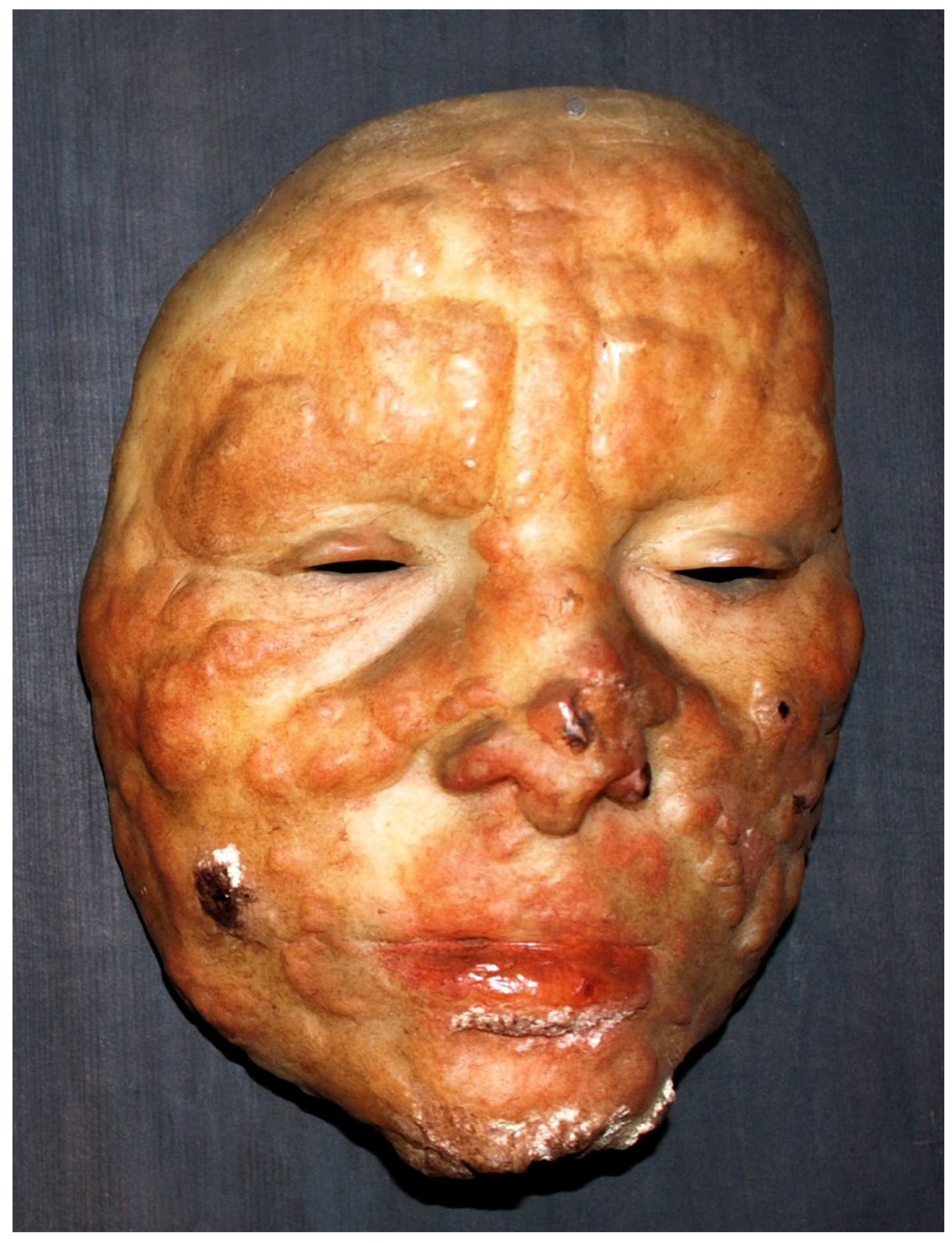

Leprosy, NO-1 collection

$99 \times 131 \mathrm{~mm}(300 \times 300$ DPI $)$ 


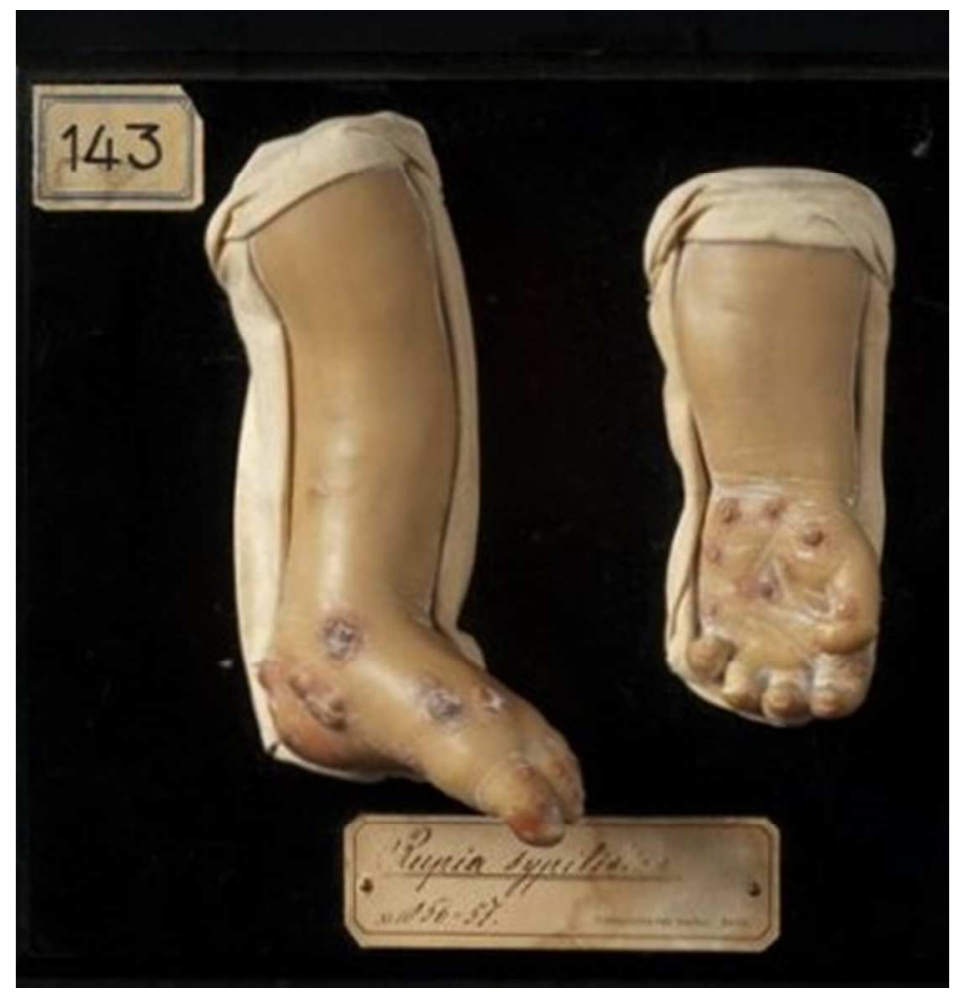

"Rupia syfilitica", SE-1 collection $94 \times 99 \mathrm{~mm}(96 \times 96 \mathrm{DPI})$ 
Authors are responsible for disclosing all financial and personal relationships between themselves and others that might be perceived by others as biasing their work. The JEADV Editors ask that all authors (not just the Corresponding Author) complete the following form.

For Co-authors: Please complete questions 4-10. Completed forms should be saved, and emailed as an attachment to the Corresponding Author.

For Corresponding Authors: Please complete all questions. It is the responsibility of the Corresponding Author to submit completed forms on behalf of all co-authors via Manuscript Central at the point of manuscript submission.

\title{
Corresponding author only (Co-authors go to Question 4):
}

POTENTIAL STUDY INTERPRETATION CONFLICTS

1. Some or all of the data that were used in this study were provided by a company with a vested interest in the product being studied.

2. The sponsor of this project had the right of commenting but the authors retained the right to accept or reject comments or suggestions.

3. The sponsor of this project had the right of final editing and/or approval of the manuscript submitted.

NO

\section{Corresponding author and Co-authors:} POTENTIAL FINANCIAL CONFLICTS

4. I, my spouse, or one of my dependent children is an employee of a company whose product is being studied.

5. I, my spouse, or one of my dependent children has significant equity interest (>USD10,000) in the company that owns the product being studied.

6. In the past three years I have:

\begin{abstract}
been paid as a consultant (or in a similar capacity) by a company with a vested interest in the product being studied, on issues related to the product being studied;

been paid as a consultant (or in a similar capacity) by a company with a vested interest in the product being studied, on issues unrelated to the product being studied;

received unrestricted research or educational support from a company with a vested interest in the product(s) being studied.
\end{abstract}

If you have answered YES to any of the above questions, or if you have additional personal, commercial or academic conflicts of interest, please draft a statement to publish with the article. e.g., AB has been reimbursed by Safe Drugs Ltd. for international conference attendance.

8. Manuscript title

Dermatological moulage collections in the Nordic countries

Full name

Ion Meyer

0. In checking this box, I confirm I have completed this form to the best of my knowledge. 
Authors are responsible for disclosing all financial and personal relationships between themselves and others that might be perceived by others as biasing their work. The JEADV Editors ask that all authors (not just the Corresponding Author) complete the following form.

For Co-authors: Please complete questions 4-10. Completed forms should be saved, and emailed as an attachment to the Corresponding Author.

For Corresponding Authors: Please complete all questions. It is the responsibility of the Corresponding Author to submit completed forms on behalf of all co-authors via Manuscript Central at the point of manuscript submission.

\title{
Corresponding author only (Co-authors go to Question 4):
}

POTENTIAL STUDY INTERPRETATION CONFLICTS

1. Some or all of the data that were used in this study were provided by a company with a vested interest in the product being studied.

2. The sponsor of this project had the right of commenting but the authors retained the right to accept or reject comments or suggestions.

3. The sponsor of this project had the right of final editing and/or approval of the manuscript submitted.

NO

\section{Corresponding author and Co-authors:} POTENTIAL FINANCIAL CONFLICTS

4. I, my spouse, or one of my dependent children is an employee of a company whose product is being studied.

5. I, my spouse, or one of my dependent children has significant equity interest (>USD10,000) in the company that owns the product being studied.

6. In the past three years I have:

\begin{abstract}
been paid as a consultant (or in a similar capacity) by a company with a vested interest in the product being studied, on issues related to the product being studied;

been paid as a consultant (or in a similar capacity) by a company with a vested interest in the product being studied, on issues unrelated to the product being studied;

received unrestricted research or educational support from a company with a vested interest in the product(s) being studied.
\end{abstract}

NO

If you have answered YES to any of the above questions, or if you have additional personal, commercial or academic conflicts of interest, please draft a statement to publish with the article. e.g., AB has been reimbursed by Safe Drugs Ltd. for international conference attendance.

8. Manuscript title

Dermatological moulage collections in the Nordic countries

9. Full name

Anne-Marie Worm

10. In checking this box, I confirm I have completed this form to the best of my knowledge. 
Authors are responsible for disclosing all financial and personal relationships between themselves and others that might be perceived by others as biasing their work. The JEADV Editors ask that all authors (not just the Corresponding Author) complete the following form.

For Co-authors: Please complete questions 4-10. Completed forms should be saved, and emailed as an attachment to the Corresponding Author.

For Corresponding Authors: Please complete all questions. It is the responsibility of the Corresponding Author to submit completed forms on behalf of all co-authors via Manuscript Central at the point of manuscript submission.

\title{
Corresponding author only (Co-authors go to Question 4):
}

POTENTIAL STUDY INTERPRETATION CONFLICTS

1. Some or all of the data that were used in this study were provided by a company with a vested interest in the product being studied.

2. The sponsor of this project had the right of commenting but the authors retained the right to accept or reject comments or suggestions.

3. The sponsor of this project had the right of final editing and/or approval of the manuscript submitted.

NO

\section{Corresponding author and Co-authors:} POTENTIAL FINANCIAL CONFLICTS

4. I, my spouse, or one of my dependent children is an employee of a company whose product is being studied.

5. I, my spouse, or one of my dependent children has significant equity interest (>USD10,000) in the company that owns the product being studied.

6. In the past three years I have:

\begin{abstract}
been paid as a consultant (or in a similar capacity) by a company with a vested interest in the product being studied, on issues related to the product being studied;

been paid as a consultant (or in a similar capacity) by a company with a vested interest in the product being studied, on issues unrelated to the product being studied;

received unrestricted research or educational support from a company with a vested interest in the product(s) being studied.
\end{abstract}

If you have answered YES to any of the above questions, or if you have additional personal, commercial or academic conflicts of interest, please draft a statement to publish with the article. e.g., AB has been reimbursed by Safe Drugs Ltd. for international conference attendance.

8. Manuscript title

Dermatological moulage collections in the Nordic countries

Full name

Henna Sinisalo

0. In checking this box, I confirm I have completed this form to the best of my knowledge. 
Authors are responsible for disclosing all financial and personal relationships between themselves and others that might be perceived by others as biasing their work. The JEADV Editors ask that all authors (not just the Corresponding Author) complete the following form.

For Co-authors: Please complete questions 4-10. Completed forms should be saved, and emailed as an attachment to the Corresponding Author.

For Corresponding Authors: Please complete all questions. It is the responsibility of the Corresponding Author to submit completed forms on behalf of all co-authors via Manuscript Central at the point of manuscript submission.

\title{
Corresponding author only (Co-authors go to Question 4):
}

POTENTIAL STUDY INTERPRETATION CONFLICTS

1. Some or all of the data that were used in this study were provided by a company with a vested interest in the product being studied.

2. The sponsor of this project had the right of commenting but the authors retained the right to accept or reject comments or suggestions.

3. The sponsor of this project had the right of final editing and/or approval of the manuscript submitted.

NO

\section{Corresponding author and Co-authors:} POTENTIAL FINANCIAL CONFLICTS

4. I, my spouse, or one of my dependent children is an employee of a company whose product is being studied.

5. I, my spouse, or one of my dependent children has significant equity interest (>USD10,000) in the company that owns the product being studied.

6. In the past three years I have:

\begin{abstract}
been paid as a consultant (or in a similar capacity) by a company with a vested interest in the product being studied, on issues related to the product being studied;

been paid as a consultant (or in a similar capacity) by a company with a vested interest in the product being studied, on issues unrelated to the product being studied;

received unrestricted research or educational support from a company with a vested interest in the product(s) being studied.
\end{abstract}

NO

If you have answered YES to any of the above questions, or if you have additional personal, commercial or academic conflicts of interest, please draft a statement to publish with the article. e.g., AB has been reimbursed by Safe Drugs Ltd. for international conference attendance.

8. Manuscript title

Dermatological moulage collections in the Nordic countries

9. Full name

Grete Eilertsen

10. In checking this box, I confirm I have completed this form to the best of my knowledge. 
Authors are responsible for disclosing all financial and personal relationships between themselves and others that might be perceived by others as biasing their work. The JEADV Editors ask that all authors (not just the Corresponding Author) complete the following form.

For Co-authors: Please complete questions 4-10. Completed forms should be saved, and emailed as an attachment to the Corresponding Author.

For Corresponding Authors: Please complete all questions. It is the responsibility of the Corresponding Author to submit completed forms on behalf of all co-authors via Manuscript Central at the point of manuscript submission.

\title{
Corresponding author only (Co-authors go to Question 4):
}

POTENTIAL STUDY INTERPRETATION CONFLICTS

1. Some or all of the data that were used in this study were provided by a company with a vested interest in the product being studied.

2. The sponsor of this project had the right of commenting but the authors retained the right to accept or reject comments or suggestions.

NO

3. The sponsor of this project had the right of final editing and/or approval of the manuscript submitted.

NO

\section{Corresponding author and Co-authors:} POTENTIAL FINANCIAL CONFLICTS

4. I, my spouse, or one of my dependent children is an employee of a company whose product is being studied.

5. I, my spouse, or one of my dependent children has significant equity interest (>USD10,000) in the company that owns the product being studied.

6. In the past three years I have:

\begin{abstract}
been paid as a consultant (or in a similar capacity) by a company with a vested interest in the product being studied, on issues related to the product being studied;

been paid as a consultant (or in a similar capacity) by a company with a vested interest in the product being studied, on issues unrelated to the product being studied;

received unrestricted research or educational support from a company with a vested interest in the product(s) being studied.
\end{abstract}

NO

7. A company whose product is being studied has provided funding to support the work on this project.

NO

If you have answered YES to any of the above questions, or if you have additional personal, commercial or academic conflicts of interest, please draft a statement to publish with the article. e.g., AB has been reimbursed by Safe Drugs Ltd. for international conference attendance.

8. Manuscript title

Dermatological moulage collections in the Nordic countries

Full name

Eva Åhrén

0. In checking this box, I confirm I have completed this form to the best of my knowledge. 